\title{
PROSES NETRALISASI PH PADA AIR GAMBUT DI DESA SAWAHAN KECAMATAN CERBON KABUPATEN BARITO KUALA
}

\author{
Sulaiman Hamzani, Munawar Raharja, Zulfikar Ali As \\ Poltekkes Kemenkes Banjarmasin Jurusan Kesehatan Lingkungan \\ Jl. H. Mistar Cokrokusumo No.1A Banjarbaru Kalimantan Selatan 70714 \\ E-mail: sulaiman_hamzani@yahoo.co.id
}

\begin{abstract}
The Neutralization Process of pH on Peat Water in Desa Sawahan Kecamatan Cerbon Kabupaten Barito Kuala. Desa Sawahan, Kecamatan Cerbon, Kabupaten Barito Kuala, located in the area of peatlands with a $\mathrm{pH}$ of water, based on laboratory results, is 3.0. This condition is classified as extreme acid, because $\mathrm{pH}$ less than 3.5. Neutralization of the peat water aimed to change the $\mathrm{pH}$ or acidity of the water to be normal ( $\mathrm{pH} 7-8)$ and could help the next process. To raise the $\mathrm{pH}$ of acidic water, quicklime $(\mathrm{CaO})$ or limestone $(\mathrm{CaCO})$ was very appropriate, because they were cheap and easy to be applied. This study is experimental, the laboratory-scale trials with variations: the concentration of solubility of lime and jartest, to obtain the optimum dose of coagulant for improving the quality of $\mathrm{pH}$. Results of the experiments on the variation of the solubility of limestone with varying concentrations showed relatively similar results, ie at a concentration of $1.0 \%$, the $\mathrm{pH}$ of the water became 12.49 ; at a concentration of $0.5 \%$, the $\mathrm{pH}$ of the water became 12.47 , and at a concentration of $0.1 \%$, the $\mathrm{pH}$ of the water became 12.18. In the next test, the addition of lime solution with a concentration of $0.5 \%$ as much as $9 \mathrm{~mL}$ in $500 \mathrm{~mL}$ peat water sample were able to raise the $\mathrm{pH}$ from 4.06 to 7.77 . Jar test results showed that the injection of $5 \mathrm{~mL}$ solution of lime and alum $2 \mathrm{~mL}$ were able to raise the $\mathrm{pH}$ of peat water from 4.02 to be 7.24 so as to meet the requirements of drinking water with $\mathrm{pH}$ 6.5-8.5. To neutralize the peat water with a $\mathrm{pH}$ of 4 is required optimum dose of lime solution with a concentration of $0.5 \%$ as much as $5 \mathrm{~mL}(50 \mathrm{mg} / \mathrm{L})$ and alum solution with a concentration of $0.5 \%$ as much as $2 \mathrm{~mL}(20 \mathrm{mg} / \mathrm{L})$.
\end{abstract}

Keywords: Neutralization of pH; peat water; jartest.

\begin{abstract}
Abstrak: Proses Netralisasi pH pada Air Gambut di Desa Sawahan Kecamatan Cerbon Kabupaten Barito Kuala. Survey yang dilakukan di Desa Sawahan Kecamatan Cerbon Kabupaten Barito Kuala, diketahui bahwa daerah tersebut berada di wilayah tanah bergambut dan hasil pemeriksaan laboratorium terhadap $\mathrm{pH}$ air adalah 3,0. Kondisi ini termasuk kategori ekstrim asam jika $\mathrm{pH}<3,5$. Proses netralisasi yang dilakukan bertujuan mengubah $\mathrm{pH}$ atau keasaman air dapat menjadi normal (pH 7-8) dan membantu proses selanjutnya. Untuk air yang bersifat asam, yang paling murah dan mudah adalah pemberian kapur tohor $(\mathrm{CaO})$ atau batu gamping $\left(\mathrm{CaCO}_{3}\right)$. Penelitian yang dilakukan bersifat eksperimental yaitu ujicoba skala laboratorium dengan variasi konsentrasi kelarutan kapur dan uji jartest untuk memperoleh dosis optimum bahan koagulan dalam memperbaiki kualitas $\mathrm{pH}$. Hasil percobaan pada variasi kelarutan kapur dengan konsentrasi yang berbeda menunjukkan hasil relatif sama yaitu konsentrasi $1,0 \% \mathrm{pH}$ air menjadi 12,49 ; konsentrasi $0,5 \% \mathrm{pH}$ air menjadi 12,47 dan konsentrasi $0,1 \% \mathrm{pH}$ air menjadi 12,18 . Pada uji lanjutan larutan kapur konsentrasi $0,5 \%$ sebesar $9 \mathrm{~mL}$ pada $500 \mathrm{~mL}$ sampel air gambut mampu menaikkan pH 4,06 menjadi 7,77. Hasil uji jartest menunjukkan injeksi larutan kapur 5 mL dan tawas $2 \mathrm{~mL}$ mampu menaikkan pH air baku 4,02 menjadi 7,24 memenuhi persyaratan air minum $\mathrm{pH}$ 6,5 - 8,5. Dosis optimum proses netralisasi $\mathrm{pH} \pm 4$ pada air gambut adalah konsentrasi larutan kapur 0,5\% sebesar $5 \mathrm{~mL}(50 \mathrm{mg} / \mathrm{L})$ dan konsentrasi larutan tawas $0,5 \%$ sebesar $2 \mathrm{~mL}(20 \mathrm{mg} / \mathrm{L})$.
\end{abstract}

Kata Kunci: Netralisasi pH; air gambut; uji jartest. 


\section{PENDAHULUAN}

Survey yang dilakukan di Desa Sawahan Kecamatan Cerbon Kabupaten Barito Kuala, diketahui bahwa daerah tersebut berada di wilayah tanah bergambut dan hasil pemeriksaan laboratorium terhadap kualitas $\mathrm{pH}$ air adalah 3,0. Kondisi ini menunjukkan kualitas air termasuk kategori ekstrim masam jika $\mathrm{pH}<3,5$. Ciri umum air gambut adalah intensitas warna yang tinggi kuning atau merah kecoklatan, $\mathrm{pH}$ rendah 2-5, rasanya masam, kadar organik tinggi, kadar besi dan mangan tinggi. Senyawa utama dalam air gambut adalah asam humat, asam fulvat, dan humin yang merupakan zat pewarna hasil pelarutan humus yang terdapat di tanah gambut. Asam humat mempunyai berat molekul yang tinggi dan berwarna coklat hingga hitam. Asam fulvat adalah bagian dari zat humat yang memilki sifat larut di dalam air, baik dalam suasana asam maupun suasana basa. Asam fulvat memiliki warna kuning emas hingga kuning coklat. Sedangkan humin merupakan bagian dari zat humat yang tidak larut di dalam air dan memilki warna hitam [1]. Air gambut dari segi kesehatan dapat menyebabkan kerusakan gigi dan sakit perut. Data Puskesmas Bantuil [2], yaitu terjadi peningkatan kasus penyakit diare tahun 2014 ada 265 kasus dibanding tahun 2013 ada 195 kasus. Masyarakat Desa Sawahan ternyata masih menggunakan air gambut untuk keperluan sehari-hari.

Penelitian ntuk mengubah karakteristik air gambut menjadi layak konsumsi, telah dilakukan oleh Fitria.,et al., [3], Said.,et al., Syarfi., et al., [4], Yusnimar et al., [5] dan Sutapa [6] telah berhasil mengolah air gambut menjadi air yang memenuhi persyaratan sebagai air minum. Namun sebagian peralatan yang digunakan dalam proses penelitian yang dilakukan relatif susah didapat di pedesaan. Sementara masyarakat yang tinggal di kawasan lahan gambut (air gambut) pada umumnya tergolong masyarakat yang kurang mampu secara penguasaan teknologi. Untuk memecahkan masalah ini telah dilakukan penelitian laboratorium dengan seperangkat alat yang sederhana dan menggunakan bahan kimia yang mudah didapat di daerah gambut dengan metode netralisasi-koagulasi-flokulasi.

Netralisasi adalah proses untuk mengubah $\mathrm{pH}$ atau keasaman air agar menjadi normal, sedangkan koagulasi didefinisikan sebagai proses destabilisasi muatan koloid padatan tersuspensi termasuk bakteri dan virus dengan suatu koagulan, sehingga terbentuk flok-flok halus yang dapat diendapkan. Flokulasi merupakan proses pembentukan flok, yang pada dasarnya merupakan pengelompokkan atau aglomerasi antara partikel dengan koagulan dengan pengadukan yang lambat [7].. Hasil penelitian Suherman dan Sumawijaya [8], untuk proses netralisasi dalam rangka menaikkan nilai pH air gambut dari 3,92 menjadi 11 diperlukan kapur tohor sebanyak 0,14 gram. Menurut Ravina [9], Duan dan Gregory [10], koagulan tawas pada proses koagulasi berfungsi secara optimum pada nilai pH antara 5 hingga 8. Saat ini di pasaran banyak dijumpai koagulan tambahan (coagulant aid) seperti super flok, magni flok, dan aqua flok yang berfungsi untuk mempercepat proses pengendapan sehingga dosis koagulan bisa berkurang [11]. Berdasarkan latar belakang, maka percobaan dengan perlakuan proses netralisasi terhadap $\mathrm{pH}$ air gambut ini diharapkan dapat memberikan solusi, mengingat masih banyak wilayah yang memiliki kesamaan kondisi geografis dan memerlukan air yang memenuhi persyaratan terutama dalam hal mengatasi kondisi air ekstrim masam.

\section{BAHAN DAN CARA PENELITIAN}

Penelitian yang dilakukan bersifat eksperimental yaitu ujicoba proses netralisasi skala laboratorium dengan melakukan variasi konsentrasi kelarutan kapur dan melakukan uji jartest untuk memperoleh dosis optimum bahan koagulan dalam memperbaiki kualitas $\mathrm{pH}$.

Sampel air gambut diambil di Desa Sawahan Kecamatan Cerbon Kabupaten Barito Kuala. Metoda sampling yang 
digunakan adalah grab sample, yaitu pengambilan sampel air sesaat. Metoda ini untuk volume sampel air yang diambil langsung dari tempat yang diteliti. Sampel air sesaat ini dianggap mewakili keadaan air pada saat itu juga dari badan air.

Data hasil penelitian ditampilkan dalam bentuk tabel dan grafik. Hasil percobaan dibandingkan dengan Peraturan Menteri Kesehatan Republik Indonesia (PERMENKES RI) Nomor 492/MENKES/PER/IV/2010 tentang persyaratan kualitas air minum [12].

\section{HASIL PENELITIAN DAN PEMBAHASAN}

Kegiatan penelitian dimulai pada tanggal 2 Agustus 2016 dilakukan pemeriksaan parameter lapangan menggunakan kertas lakmus pada air baku, diketahui kualitas pH air adalah 4 . Kemudian dilakukan pengambilan sampel air gambut sebanyak 2 jirigen x @ 20 Liter sebagai air baku untuk percobaan yang dilakukan di Laboratorium Jurusan Kesehatan Lingkungan Poltekkes Kemenkes Banjarmasin. Berdasarkan pemeriksaan laboratorium menggunakan alat $\mathrm{pH}$ meter diketahui $\mathrm{pH} 4,06$. Sebelum dilakukan uji jartest, terlebih dahulu dilakukan uji kelarutan kapur menggunakan air baku berasal dari PDAM untuk mengetahui tingkat kelarutan kapur pada konsentrasi yang berbeda. Adapun hasil ujicoba variasi kelarutan kapur dapat dilihat pada tabel 1 berikut:

Tabel 1. Hasil Ujicoba Variasi Kelarutan Kapur

\begin{tabular}{cccc}
\hline No & Konsentrasi Kapur & Jumlah Air Baku PDAM & $\begin{array}{c}\text { pH Air Setelah ditambahkan } \\
\text { Kapur }\end{array}$ \\
\hline 1. & $1,0 \%$ & $500 \mathrm{~mL}$ & 12,49 \\
2. & $0,5 \%$ & $500 \mathrm{~mL}$ & 12,47 \\
3. & $0,1 \%$ & $500 \mathrm{~mL}$ & 12,18 \\
\hline
\end{tabular}

Berdasarkan tabel 1 diketahui bahwa $\mathrm{pH}$ naik pada kisaran angka yang sama. Selanjutnya dilakukan ujicoba konsentrasi larutan kapur terdiri dari: konsentrasi 1,0\%; 0,5\%; 0,1\% untuk menaikkan $\mathrm{pH}$ air gambut, dimana $\mathrm{pH}$ sampel air baku adalah 4,06. Ujicoba dilakukan dengan menginjeksi masingmasing larutan kapur tersebut pada 3 buah bekerglass berisi $500 \mathrm{~mL}$ sampel air baku. Hasil ujicoba variasi konsentrasi kapur dengan injeksi 1-2 mL dapat dilihat pada tabel 2 berikut:

Tabel 2. Hasil Ujicoba Variasi Konsentrasi Kapur dengan Injeksi 1-2 mL

\begin{tabular}{ccccc}
\hline No & $\begin{array}{c}\text { Konsentrasi } \\
\text { Kapur }\end{array}$ & $\begin{array}{c}\text { Jumlah Injeksi } \\
\text { Kapur }\end{array}$ & $\begin{array}{c}\text { pH Air Baku } \\
\text { Sebelum Injeksi } \\
\text { Kapur }\end{array}$ & $\begin{array}{c}\text { pH Air Baku Setelah } \\
\text { Injeksi Kapur }\end{array}$ \\
\hline 1. & $1,0 \%$ & $1 \mathrm{~mL}$ & 4,06 & 4,44 \\
2. & $0,5 \%$ & $1 \mathrm{~mL}$ & 4,06 & 4,36 \\
3. & $0,1 \%$ & $1 \mathrm{~mL}$ & 4,06 & 4,15 \\
4. & $1,0 \%$ & $2 \mathrm{~mL}$ & 4,06 & 4,60 \\
5. & $0,5 \%$ & $2 \mathrm{~mL}$ & 4,06 & 4,62 \\
6. & $0,1 \%$ & $2 \mathrm{~mL}$ & 4,06 & 4,36 \\
\hline
\end{tabular}

Tabel 2 di atas menunjukan kenaikan $\mathrm{pH}$ relatif sama pada konsentrasi yang berbeda, sehingga ujicoba dilanjutkan dengan memilih konsentrasi kapur 0,5\% pada sampel air baku $500 \mathrm{~mL}$ pada tabel 3 . 
Tabel 3. Hasil Ujicoba Variasi Injeksi Kapur 3 mL s/d 10 mL Konsentrasi 0,5 \%

\begin{tabular}{|c|c|c|c|c|c|}
\hline No & \multicolumn{2}{|c|}{ Konsentrasi Kapur } & $\begin{array}{l}\text { Jumlah Injeksi } \\
\text { Kapur }\end{array}$ & $\begin{array}{c}\text { pH Air Baku } \\
\text { Sebelum Injeksi } \\
\text { Kapur } \\
\end{array}$ & $\begin{array}{c}\text { pH Air Baku } \\
\text { Setelah Injeksi } \\
\text { Kapur } \\
\end{array}$ \\
\hline 1. & $0,5 \%$ & $3 \mathrm{~mL}$ & 4,06 & & 4,91 \\
\hline 2. & $0,5 \%$ & $4 \mathrm{~mL}$ & 4,06 & & 5,34 \\
\hline 3. & $0,5 \%$ & $5 \mathrm{~mL}$ & 4,06 & & 5,64 \\
\hline 4. & $0,5 \%$ & $6 \mathrm{~mL}$ & 4,06 & & 5,98 \\
\hline 5. & $0,5 \%$ & $7 \mathrm{~mL}$ & 4,06 & & 6,33 \\
\hline 6. & $0,5 \%$ & $8 \mathrm{~mL}$ & 4,06 & & 6,78 \\
\hline 7. & $0,5 \%$ & $9 \mathrm{~mL}$ & 4,06 & & 7,77 \\
\hline 8. & $0,5 \%$ & $10 \mathrm{~mL}$ & 4,06 & & 9,07 \\
\hline
\end{tabular}

Tabel 3 di atas menunjukan bahwa injeksi larutan kapur $9 \mathrm{~mL}$ pada $500 \mathrm{~mL}$ sampel air baku mampu menaikkan $\mathrm{pH}$ dari 4,06 menjadi pH 7,77 sesuai dengan persyaratan kualitas air minum untuk $\mathrm{pH}$ 6,5- 8,5. Percobaan berikut dilakukan pada $500 \mathrm{~mL}$ sampel air baku $\mathrm{pH} 4,01$ dengan menambah larutan tawas konsentrasi $0,5 \%$ dengan variasi dosis 1 $\mathrm{mL} \mathrm{s} / \mathrm{d} 9 \mathrm{~mL}$ yang sebelumnya diinjeksi dengan larutan kapur $9 \mathrm{~mL}$ konsentrasi $0,5 \%$ seperti dapat dilihat pada tabel 4 berikut:

Tabel 4. Hasil Ujicoba Injeksi Kapur 9 mL Konsentrasi 0,5 \% dan Variasi Injeksi Tawas $1 \mathrm{~mL}$ s/d 9 mL Konsentrasi 0,5\%

\begin{tabular}{ccccccc}
\hline No & $\begin{array}{c}\text { pH Air } \\
\text { Baku }\end{array}$ & $\begin{array}{c}\text { Konsentrasi } \\
\text { Kapur dan } \\
\text { Tawas }\end{array}$ & $\begin{array}{c}\text { Jumlah } \\
\text { Injeksi } \\
\text { Kapur }\end{array}$ & $\begin{array}{c}\text { pH Air } \\
\text { Setelah } \\
\text { Injeksi } \\
\text { Kapur }\end{array}$ & $\begin{array}{c}\text { Jumlah } \\
\text { Injeksi } \\
\text { Tawas }\end{array}$ & $\begin{array}{c}\text { pH Air Setelah } \\
\text { Injeksi Tawas }\end{array}$ \\
\hline 1. & 4,01 & $0,5 \%$ & $9 \mathrm{~mL}$ & 9,98 & $1 \mathrm{~mL}$ & 9,82 \\
2. & 4,01 & $0,5 \%$ & $9 \mathrm{~mL}$ & 9,98 & $2 \mathrm{~mL}$ & 9,62 \\
3. & 4,01 & $0,5 \%$ & $9 \mathrm{~mL}$ & 9,98 & $3 \mathrm{~mL}$ & 9,34 \\
4. & 4,01 & $0,5 \%$ & $9 \mathrm{~mL}$ & 9,98 & $4 \mathrm{~mL}$ & 9,03 \\
5. & 4,01 & $0,5 \%$ & $9 \mathrm{~mL}$ & 9,98 & $5 \mathrm{~mL}$ & 8,73 \\
6. & 4,01 & $0,5 \%$ & $9 \mathrm{~mL}$ & 9,98 & $6 \mathrm{~mL}$ & 8,47 \\
7. & 4,01 & $0,5 \%$ & $9 \mathrm{~mL}$ & 9,98 & $7 \mathrm{~mL}$ & 8,19 \\
8. & 4,01 & $0,5 \%$ & $9 \mathrm{~mL}$ & 9,98 & $8 \mathrm{~mL}$ & 7,81 \\
9. & 4,01 & $0,5 \%$ & $9 \mathrm{~mL}$ & 9,98 & $9 \mathrm{~mL}$ & 7,41 \\
\hline
\end{tabular}

Tabel 4 di atas menunjukan bahwa pada injeksi larutan kapur $9 \mathrm{~mL}$ dan larutan tawas $9 \mathrm{~mL}$ mampu menaikkan pH air baku dari 4,01 menjadi 7,41 telah memenuhi persyaratan kualitas air minum untuk pH 6,5 - 8,5. Pada percobaan selanjutnya kondisi larutan kapur diaduk terus menerus agar tidak mengendap di bawah. Berikut hasil uji jartest menggunakan injeksi larutan kapur 0,5\% sebesar $5 \mathrm{ml}$ dan injeksi variasi larutan tawas 0,5 \% masingmasing $1 \mathrm{~mL} ; 2 \mathrm{~mL} ; 3 \mathrm{~mL} ; 4 \mathrm{~mL}$ dan $5 \mathrm{~mL}$ pada tabel 5 dan tabel 6 berikut: 
Tabel 5. Hasil Uji jartest Perlakuan I

\begin{tabular}{cccccc}
\hline No & $\begin{array}{c}\text { pH Air } \\
\text { Baku }\end{array}$ & $\begin{array}{c}\text { Konsentrasi } \\
\text { Tawas dan Kapur }\end{array}$ & $\begin{array}{c}\text { Jumlah } \\
\text { Injeksi Kapur }\end{array}$ & $\begin{array}{c}\text { Jumlah } \\
\text { Injeksi Tawas }\end{array}$ & $\begin{array}{c}\text { pH Setelah } \\
\text { Perlakuan }\end{array}$ \\
\hline 1. & 4,01 & 0 & 0 & 0 & 4,25 \\
2. & 4,04 & $0,5 \%$ & $5 \mathrm{~mL}$ & $1 \mathrm{~mL}$ & 6,66 \\
3. & 4,02 & $0,5 \%$ & $5 \mathrm{~mL}$ & $2 \mathrm{~mL}$ & 7,24 \\
4. & 4,01 & $0,5 \%$ & $5 \mathrm{~mL}$ & $3 \mathrm{~mL}$ & 7,28 \\
5. & 4,00 & $0,5 \%$ & $5 \mathrm{~mL}$ & $4 \mathrm{~mL}$ & 7,17 \\
6. & 4,02 & $0,5 \%$ & $5 \mathrm{~mL}$ & $5 \mathrm{~mL}$ & 7,08 \\
\hline
\end{tabular}

Tabel 6. Hasil Uji jartest Perlakuan II

\begin{tabular}{cccccc}
\hline No & $\begin{array}{c}\text { pH Air } \\
\text { Baku }\end{array}$ & $\begin{array}{c}\text { Konsentrasi } \\
\text { Tawas dan Kapur }\end{array}$ & $\begin{array}{c}\text { Jumlah } \\
\text { Injeksi Kapur }\end{array}$ & $\begin{array}{c}\text { Jumlah } \\
\text { Injeksi Tawas }\end{array}$ & $\begin{array}{c}\text { pH Setelah } \\
\text { Perlakuan }\end{array}$ \\
\hline 1. & 4,12 & 0 & 0 & 0 & 4,12 \\
2. & 4,17 & $0,5 \%$ & $5 \mathrm{~mL}$ & $1 \mathrm{~mL}$ & 6,81 \\
3. & 4,18 & $0,5 \%$ & $5 \mathrm{~mL}$ & $2 \mathrm{~mL}$ & 7,34 \\
4. & 4,18 & $0,5 \%$ & $5 \mathrm{~mL}$ & $3 \mathrm{~mL}$ & 7,43 \\
5. & 4,19 & $0,5 \%$ & $5 \mathrm{~mL}$ & $4 \mathrm{~mL}$ & 7,35 \\
6. & 4,18 & $0,5 \%$ & $5 \mathrm{~mL}$ & $5 \mathrm{~mL}$ & 7,22 \\
\hline
\end{tabular}

Tabel 5 dan tabel 6 di atas menunjukan bahwa injeksi larutan kapur $5 \mathrm{~mL}$ dan tawas $2 \mathrm{~mL}$ mampu menaikkan pH air baku 4,02 dan 4,18 menjadi 7,24 dan 7,34 memenuhi persyaratan kualitas air untuk pH 6,5 - 8,5. Berdasarkan hasil uji jartest tersebut, maka dosis optimum yang dapat digunakan untuk memperbaiki kualitas air gambut dengan $\mathrm{pH} \pm 4$ dapat menggunakan konsentrasi larutan kapur 0,5 \% sebesar $5 \mathrm{~mL}$ (50 $\mathrm{mg} / \mathrm{L}$ ) dan konsentrasi larutan tawas 0,5 $\%$ sebesar $2 \mathrm{~mL}(20 \mathrm{mg} / \mathrm{L})$.

Dalam pengolahan air bahan dual coagulants dapat ditambahkan ke air secara terpisah atau tercampur [9]. Penelitian kelarutan oleh Edzwald dan Benschoten menyebutkan bahwa presipitat $\mathrm{Al}(\mathrm{OH})_{3}$ mulai terbentuk pada $\mathrm{pH}<4,5$ dan $\mathrm{pH}>8,0$ sebagian besar aluminium hadir sebagai species terlarut. Penggunaan tawas sebagai koagulan dapat bekerja dengan baik pada $\mathrm{pH}$ 6,5-7 [13]. Penelitian Puteri menyebutkan bahwa ukuran flok yang besar akan mempercepat proses pengendapan, sehingga flok lebih mudah dipisahkan [11].. Menurut Hendricks, alkalinitas akan bereaksi dengan ion $\mathrm{H}^{+}$untuk menjaga $\mathrm{pH}$ tetap stabil, jika penambahan kapur tidak mampu menaikkan nilai pH menandakan bahwa alkalinitas dalam air rendah [14]. Penelitian Bo dkk., menyimpulkan efisiensi koagulasi dapat ditingkatkan secara signifikan dengan menggunakan kombinasi dua bahan koagulan [13]. Kasus yang sering terjadi dalam penggunaan tawas karena terbentuknya sulfat dalam air mengakibatkan kebutuhan bahan penetral seperti kapur menjadi lebih banyak, sementara alkalinitas air baku tidak mencukupi untuk bereaksi dengan tawas [15]. Kelemahan utama penggunaan tawas sebagai koagulan adalah ketidakmampuan mengontrol sifat koagulan yang terbentuk dan bersaing dengan reaksi lain, akibatnya kinerja tawas memburuk dengan perubahan suhu dan sifat air baku. Kondisi ini akan merubah dosis koagulan dan $\mathrm{pH}$ [16].

Semakin banyak jumlah tawas yang ditambahkan dalam air, maka meningkatkan keasaman air dan meyebabkan $\mathrm{pH}$ semakin turun. Jika tingkat keasaman air tinggi, maka dosis larutan kapur yang dibutuhkan semakin besar pula untuk menetralkan air olahan. Penurunan $\mathrm{pH}$ tersebut terjadi karena adanya reaksi hidrolis $\mathrm{Al}$ yang 
membebaskan ion $\mathrm{H}+$, sehingga menekan nilai $\mathrm{pH}$ [13]. Penurunan $\mathrm{pH}$ juga terjadi karena adanya komponen yang bermuatan positif dari flok Al203 yang mengikat muatan negatif air yaitu $\mathrm{OH}-$ [17]. pH merupakan salah satu parameter yang sangat penting dalam mempengaruhi proses koagulasi-flokulasi. Menurut Marganingrum dan Noviardi, fluktuasi $\mathrm{pH}$ memberikan gambaran adanya dampak lingkungan baik secara alami maupun pengaruh adanya penambahan bahan kimia tertentu [15]. Air normal yang memenuhi syarat sebagai air baku mempunyai $\mathrm{pH}$ berkisar antara 6,5 - 7,5 [18]. Penggunaan bahan koagulan pada uji jartest (sistem batch) yang menggunakan air baku yang kualitasnya relatif tetap, $\mathrm{pH}$ air lebih mudah dikondisikan.

\section{KESIMPULAN DAN SARAN}

Hasil percobaan variasi kelarutan kapur dengan konsentrasi yang berbeda menunjukkan hasil relatif sama yaitu konsentrasi $1,0 \% \mathrm{pH}$ air menjadi 12,49 ; konsentrasi $0,5 \% \mathrm{pH}$ air menjadi 12,47 dan konsentrasi $0,1 \% \mathrm{pH}$ air menjadi 12,18. Pada percobaan lanjutan untuk larutan kapur konsentrasi 0,5\% sebesar 9 $\mathrm{mL}$ pada $500 \mathrm{~mL}$ sampel air gambut, mampu menaikkan pH dari 4,06 menjadi 7,77.

Hasil uji jartest menunjukkan bahwa injeksi larutan kapur $5 \mathrm{~mL}$ dan tawas $2 \mathrm{~mL}$ mampu menaikkan $\mathrm{pH}$ air baku 4,02 menjadi 7,24 memenuhi persyaratan kualitas air minum untuk $\mathrm{pH}$ $6,5-8,5$. Dosis optimum yang diperoleh untuk proses netralisasi $\mathrm{pH} \pm 4$ pada air gambut adalah konsentrasi larutan kapur $0,5 \%$ sebesar $5 \mathrm{~mL}(50 \mathrm{mg} / \mathrm{L})$ dan konsentrasi larutan tawas $0,5 \%$ sebesar 2 $\mathrm{mL}(20 \mathrm{mg} / \mathrm{L})$.

\section{KEPUSTAKAAN}

1. Zadow, R., (2009), THE REAL DIRT ON Humic Subtances, Maximum Yield, Canada, page 40-44.

2. Puskesmas Bantuil (2015), Data Kesehatan Lingkungan Tahun 2014, Dinkes Batola.
3. Fitria, D., dan Suprihanto, N., (2007), Penurunan Warna dan Kandungan Zat Organik Air Gambut dengan Cara Two Stage, Bandung, Jurnal Teknik Lingkungan, V. 13, No. 1, h. 17-26.

4. Syarfi, H.S., (2007), "Rejeksi Zat Organik Air Gambut Dengan Membran Ultrafiltrasi", Jurnal Sains dan Teknologi 6 (1), Program Studi Teknik Kimia, Universitas Riau, Pekanbaru, hal. 1-4.

5. Yusnimar, A. Yelmida, Yenie E., HS. Edward, Drastinawati, (2010), "Pengolahan Air Gambut Dengan Bentonit", Jurnal Sains dan Teknologi 9 (2), Jurusan Teknik Kimia, Fakultas Teknik, Universitas Riau, Pekanbaru, 77-81.

6. Sutapa, Ig.D.A., (2012), "Kajian Jar Test Koagulasi-Flokulasi Sebagai Dasar Perancangan Instlasi Pengolahan Air Gambut (IPAG) Menjadi Air Bersih", Research Centre for Limnology LIPI, http://www. Opi.lipi.go.id/data/./1308671032132 0146107, maka-lah.pdf (diakses 3 Desember 2012).

7. Risdianto, D., 2007, Optimisasi Proses Koagulasi Flokulasi Untuk Pengolahan Air Limbah Industri Jamu (Studi Kasus PT. Sido Muncul), Tesis Master, Universias Diponegoro, Semarang, epirints. undip.ac.id./ 37311 (diakses 3 Januari 2013).

8. Ravina L., (1993), Everyting You Want To Know About Coagulation and Flucolation, Zeta Meter, Inc, Staunton, Virginia

9. Kuusik dan Viisimaa (1998), "A New Dual Coagulant for Water Purification, Department of Basic and Applied Chemistry", Water Research, Vol. 33, No. 9, hal. 2075-2082.

10. Indriyani, (2008), "Proses Pengolahan Limbah Organik Secara Koagulasi dan Flokulasi", Jakarta, JRL, Vol. 4, No. 2, Hal. 125-130, Pusat Teknologi Lingkungan, BPPT.

11. Puteri, A.R. (2011), Studi Penurunan Kekeruhan Air Kali Surabaya dengan Proses Flokulasi dalam Bentuk Flokulator Pipa Circular, Skripsi 
Teknik Lingkungan, FTSP-ITS, Surabaya.

12. R.I. (2010), Peraturan Menteri Kesehatan Nomor 492/Menkes/PER/ IV/2010 Tentang Persyaratan Kualitas Air Minum, Jakarta.

13. Hendricks, D. (2006), Water Treatment Unit Processes: Physical and Chemical, CRC Press Taylor and Francis Groups, Broken Sound Parkway, New York.

14. Bo, X., Gao, B., Peng, N., Wang, Y., Yue, Q., dan Zhao, Y. (2011), "Coagulation Performance and Floc Properties of Compound Bio flocculant-Aluminum Sulfate Dual-Coagulant in Treating Kaolin-Humic Acid Solution", Chemical Engineering Journal, Vol. 173, hal. 400-406.

15. Said, N.I. (2010), Teknologi Pengolahan Air Minum, Penerbit Pusat Teknologi Lingkungan BPPT, Jakarta.

16. Gao, B.Y., Hahn, H.H., dan Hoffmann, E. (2002), "Evaluation of AluminumSilicate Polymer Composite as A Coagulant for Water Treatment", Water Research, Vol. 36, hal. 35733581.

17. Gao, B.Y., Hahn, H.H., dan Hoffmann, E. (2002), "Evaluation of AluminumSilicate Polymer Composite as A Coagulant for Water Treatment", Water Research, Vol. 36, hal. 35733581.

18. Marganingrum, D. dan Noviardi R. (2010), "Pencemaran Air dan Tanah di Kawasan Pertambangan Batubara di PT. Berau Coal Kalimantan Timur", Jurnal Riset Geologi dan Pertambangan, Vol. 20, 1, 11-20. 
466 | Jurnal Kesehatan Lingkungan Vol. 14 No. 2, Juli 2017 